(昭和 32 年 1 月 23 日受理)

\title{
ブナパルプのアルカリ老成速度につレて
}

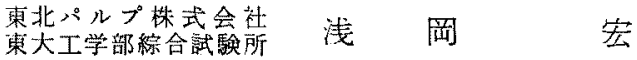

\section{ALKALI AGING OF BEECH PULP}

\author{
By Hiroshi Asaoka
}

(Tōhoku Pulp Co. Ltd., Marunouchi, Chiyoda-ku, Tokyo ; Engineering Research Institute, Faculty of Engineering, Tokyo University, Bunkyoku, Tokyo, Japan)

1. The decrease in the degree of polymerization determined by cupramonium solution viscosity, method, caused by aging of beech pulp alkali cellulose is generally thought to be faster than that of red pine pulp alkali cellulose, owing to the combination of differences in their chainlength distribu tion sand the bias in the determination of cupramonium solution viscosity, based on composition of the solution. (See our former papers.) Namely, the rate of decrease in true degree of polymerization caused by the aging of beech alkali cellulose is substantially identical with that of red pine alkali cellulose.

2. In order to explain this phenomenon quantitatively, models of chainlength distribution of beech and red pine pulp were made and changes of chainlength distribution of alkali cellulose from these pulp were calculated by OKAMURA's theory. The calculated results were compared and showed good agreements with the experimental data.

(Received 23. 1. 1957)

\section{1. 緒}

ブナパルプから彆造したアルカリセルローズの老成速 度は，赤松のそれに比し速いといるれているす。の原 因についてマンガンがアルカリ老成を促進せしめる2こ とから、ブナパルプの柔細胞中に含まれている著量のマ ンガン3゙のためとも考えられるが，片プのマンガン含 量はブナパルプの方が赤松パルプに比し多いが，いずれ にせよきわかて微量であるし゚ルプに対し $3 \sim 30 \times 10^{-5}$ \%)出苛性ソーダ中のマンガン含量(化䋐用苛性ソーダ日 本工業規格に上れば $25 \times 10^{-5} \%$ 以下となつている)を考 え合せれば，マンガン含量によつてのみ説明し5るとる 思われない。また老成速度に影響を和上ぼす因子として， パルプの潋細檴造の差簧も考えられるが，その立場より するはつきりした見解は未だ発表されておらぬ上5であ る。更に W. Bandel惊 はプナパルプのアルカリ老成を 重合度分标の変化より追跡して，䋐維素分子のい扐る 弱結合の存在に注目している。一般にアルカリセルロー ズの老成速度の測定には酸化銅アンモニア夜（銅安液） を溶媒と也る粘度法重合度を比較して求めている。一方 著者ら 一般に用いられているJIS p. 8101 に規定された組成の
銓安液を溶媒として，電合度を湘定する際には重合传 2000 前後以上のパルプの高重合度部分が測定結果関 与せず，実際の重合度よりも低く偏つた测定值をむたえ るという見解を示した。

著者の考え方によればブホパルプから慗造したアルカ リセルローズの老成速度は, 赤松パルプのそれと全く同 一であつて，それが見かけ上速く見えるのは前䇉》で示 した如くブナバルプの重合度分布が赤松パルプの重合度 分布と異なり高重合度部分が少いことによるのである。 もしも JIS 8101. に替定された如き低銓高アンモニアの 銅安液を用いてパルプの平均重合度を測定した場合，乙 の測定結果が赤松およびプナパルプ共同一で女つても䒠 際には赫松ルプの方がブナパルプよりる平均重合度の 高い場合が多く，そうでない場合です高重合度部分の影 響で見掛け上ブナパルプのアルカリセルトーズの老成速 度が，はやいよう测定されるのである。したがつて高 銅低アンモニアの組成を有する銅安液で测定す机ば，而 者の老成速度は変らない筈である。以下実驗事実につい てこの考え尔を説明する。

\section{2. アルカリセルローズの重合度低下と 鎖長の分裂率}


老成速度を比較するには平均重合度の低下を調ぺても よいが，それから鎖睘の分裂率を算出して比較する方が 反店速度恒数党直接求められる点からる便利である。鎖 長の分裂萃は鎖状分子一分子当りの切断結合数を，始め の重合度で除したものであつて，理諭的に誘導せられた 桜田・岡村両氏の式》により次の如く規定せられる。

$$
\begin{aligned}
& \frac{P v}{N}=\frac{2}{S^{2}}\left(S-1+\frac{1}{e^{s}}\right) \\
& \alpha=\frac{S}{N} \\
& こ こ に N \text { 始妨の電合度 } \\
& P v \text { 分裂後の重量平均重合度 } \\
& S \text { 一分子当りの切断結合数 } \\
& \alpha \text { 分裂 率 }
\end{aligned}
$$

(1) 武は元来均一な重合度を有する鎖状高分子が崩 壊した際の重合度変化を示寸るのでるるが，小林，丹沢 氏゙)によれば重合度分布の影響は受けずアルカリ老成の 場合にも十分適用し5るもので希る。今（1)(2) 式によ り赤松パルブおよびブナパルブのアルカy老成に怙ける 分裂率の時間的経過を計算してみると第 2 表の如くなる。 また粘度測定に使用した銅安液の組成は第 1 表の如くで ある。

第 1 表 銅安液の組成

\begin{tabular}{l|c|c}
\hline & $\mathrm{NH}_{3} \mathrm{~g} / \mathrm{l}$ & $\mathrm{Cu} \mathrm{g} / l$ \\
\hline 低銅高アンモ=ア法 & 219 & 11.4 \\
高銅低アンモニア法 & 185 & 23.6 \\
\hline
\end{tabular}

老成条件はパルプを $20^{\circ} \mathrm{C}$ において $17.5 \%$ 苛性ソーダ

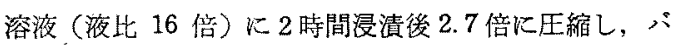
ルタナンバー $180 \mathrm{~g} / l$ になるよ5(約 2 時間)解碎したる

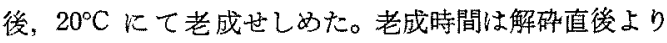

\begin{tabular}{|c|c|c|c|c|c|c|c|c|}
\hline \multirow{2}{*}{$\begin{array}{l}\text { 老成 } \\
\text { 時間 }\end{array}$} & \multicolumn{2}{|c|}{ 赤松パルプ } & \multicolumn{2}{|c|}{ ブナパルプ } & \multicolumn{2}{|c|}{$\begin{array}{l}\text { ブナパル } \\
\text { プ }-2\end{array}$} & \multicolumn{2}{|c|}{$\begin{array}{l}\text { ブナル゚ル } \\
\text { プ }-3\end{array}$} \\
\hline & \begin{tabular}{|c|} 
重侖 \\
度
\end{tabular} & $\begin{array}{l}\mid \text { 分裂率 } \\
\times 10^{4}\end{array}$ & $\mid$\begin{tabular}{|c|} 
重命 \\
度
\end{tabular} & $\begin{array}{l}\text { 分裂率 } \\
\times 10^{4}\end{array}$ & 重合 & $\begin{array}{l}\text { 分裂率 } \\
\times 10^{4}\end{array}$ & $\mid$ & $\begin{array}{l}\text { 分器率 } \\
\times 10^{4}\end{array}$ \\
\hline $\begin{array}{l}\text { 原パル } \\
\text { プ }^{\circ}\end{array}$ & 835 & 0 & 820 & 0 & 770 & 0 & 750 & 0 \\
\hline 解砝直 & 745 & 4.3 & 775 & 1.9 & - & - & - & - \\
\hline 4 & 700 & 6.7 & 680 & 7.3 & 620 & 9.0 & 620 & 8.0 \\
\hline 22 & 630 & 10.9 & 590 & 13.2 & - & - & 560 & 12.7 \\
\hline 46 & 510 & 20.4 & 420 & 29.8 & 420 & 27.3 & 440 & 24.0 \\
\hline 70 & 355 & 38.3 & - & - & 320 & 43.5 & 340 & 38.7 \\
\hline 118 & 325 & 45.5 & - & - & 290 & 52.0 & 300 & 47,4 \\
\hline
\end{tabular}
起算してある。老成試料は多量の稀醀酸溶液中に投入中 和再生後十分水洗乾燥して重合度を測定した。重合度の

\begin{tabular}{|c|c|c|c|c|c|c|c|c|}
\hline \multirow{2}{*}{$\begin{array}{l}\text { 考成 } \\
\text { 時間 }\end{array}$} & \multicolumn{2}{|c|}{ 赤松パルプ } & \multicolumn{2}{|c|}{ 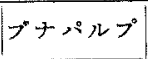 } & \multicolumn{2}{|c|}{$\begin{array}{l}\text { ブナパル } \\
\text { プ }-2\end{array}$} & \multicolumn{2}{|c|}{$\begin{array}{l}\text { プナ゙パル } \\
\text { プー3 }\end{array}$} \\
\hline & \begin{tabular}{|c|} 
電合 \\
度
\end{tabular} & $\begin{array}{l}\text { 分裂蜜 } \\
\times 10^{4}\end{array}$ & \begin{tabular}{|l} 
重合 \\
度
\end{tabular} & 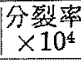 & $\mid$\begin{tabular}{|c|} 
箠合 \\
度
\end{tabular} & $\begin{array}{l}\text { 分裂率 } \\
\times 10^{4} \\
\end{array}$ & \begin{tabular}{|l|}
$\mid$ 需合 \\
度
\end{tabular} & $\begin{array}{r}93 \text { 裂点 } \\
\times 10^{4} \\
\end{array}$ \\
\hline $\begin{array}{l}\text { 原 パル } \\
\text { プ }\end{array}$ & 900 & 0 & 960 & 0 & 840 & 0 & 910 & 0 \\
\hline 解硪㨁 & 800 & 4.1 & 880 & 2.8 & - & - & - & - \\
\hline 4 & 815 & 3.3 & 850 & 4.0 & 690 & 7.4 & 780 & 5.3 \\
\hline 22 & 670 & 10.7 & 660 & 13.0 & - & - & 640 & 12.6 \\
\hline 46 & 520 & 21. 3 & 525 & 22.4 & 510 & 20.6 & 520 & 21.4 \\
\hline 70 & 380 & 36.1 & - & - & 370 & 36.3 & 370 & 37.9 \\
\hline 118 & 300 & 53.9 & - & - & 290 & 54.4 & 340 & 43.9 \\
\hline
\end{tabular}
測定法は先に示したものと全く同様であるから省略する。

第 2 表 老成アルカリ七ルロー大の重合度と分裂率 1) 低銅高アンモニア銅安液の場合
2) 高銅低アンモニア銅安湤の場合

第 2 表に見る如く低銅高アンモニア銅安液により重合 度を测定算出する時は，明らかにブナパルプの方が重合 度低下が著しく，分裂率も大であり，老成が進む作つれ て差が大きくなる。しかるに高銅低アンモニア法では殆 んど差が認められない。をた老成の末期に招いては銅安 液の組成の差による各パルプの重合度の差は認められな い。これは前報ので示したように高重合度部分が完全に なくなつて，低銅高アンモニアの銅安液に颃いてもパル プヒルロースが完全に溶解分散したためである。

\section{3. パルプの重合度分布のモデルによる 老成過程の検討}

このよ5にプナパルプより製造したアルカリセルロー ズの老成速度が，低銅高アンモニア銅安液で測定する と，赤松パルプのそれより速くみえるのは前報すに示し た如く，プナパルプが高重合度部分に之しいため，パル プの見此け上重合度が赤松パルプと等しいがたそれ 以上であつても，実際は赫松パプより低重合度である 場合が多いこと，および赤松パルプのアルカリセルロ一 ズでは老成の進行にとるなつて高重合度部分が低重合度 部分に移行して新たに粘度值に関与してくるので, 重合 度低下が緩漫となるのに，ブナパルプではその影響がな いため低下の状態が急速に見えることによるものと考え る。このことを確認するためパルプの重合度分布モデル を設定しての老成過程を推定してみた。

モデルの重合度分布は前報9の結果を参考とし第 3 表 の如く定めた。

このモデルパルプはいずれもレーシンパルプクラスで あるとし重合度 100 のフラクションを 10\% としたのは 大体 $\alpha$ 一瀻維素含有量 $90 \%$ に対応世しめんとしたからで ある。またこのモデルは現実のパルプの重合度分布を忠 実に再現したるのではなく，計算の便宜を考え両パルプ の特徽のみを強調してある。各フラクションは均一なる 重合度を有するすのとし 
第 3 表 パルプの重合度分布モデル

\begin{tabular}{|c|c|c|c|}
\hline 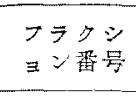 & $\begin{array}{l}\text { フラクショ } \\
\text { ン西合度 }\end{array}$ & $\begin{array}{l}\text { ブチパルプの } \\
\text { フラタジ } \\
\text { の重量 }(\%)\end{array}$ & $\begin{array}{l}\text { 柰松パルプ } \\
フ \text { ラタション } \\
\text { の雷量 }(\%)\end{array}$ \\
\hline 1 & 100 & 10.0 & 10.0 \\
\hline 2 & 300 & 20.0 & 15.0 \\
\hline 3 & 500 & 20.0 & 15.0 \\
\hline 4 & 800 & 2.5 & 10.0 \\
\hline 5 & 1000 & 2.5 & 15.0 \\
\hline 6 & 1500 & 35.0 & 20.0 \\
\hline 7 & 2000 & 10.0 & 10.0 \\
\hline 8 & 3000 & 0.0 & 5.0 \\
\hline & 合 & 100.0 & 100.0 \\
\hline \multicolumn{2}{|c|}{$\begin{array}{l}\text { 高銅低アンモ二ア銅安液 } \\
\text { で潈定した平均重合度 } \mathrm{p}^{\prime}\end{array}$} & 940 & 1010 \\
\hline \multicolumn{2}{|c|}{ 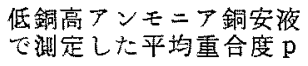 } & 822 & 765 \\
\hline
\end{tabular}

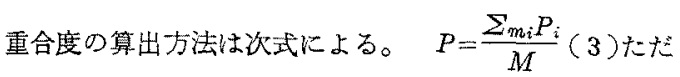
し $m i, P i$ はそれぞれ1番目のフラクションの重量パー せントおよび重合度で， $M$ は測定に関与する試料の全量 をパーセントであらわしたものである。すなわち初めの パルブ武料の場合 $i$ は 1 8, $M=100$, 老成陚料では $i$ は 2 8、 $M=90$ である。P算出する場合は箽合度 2000 以上のフラタションは関与しないから, 更に 7 番目 および 8 番目のフラクションをのぞく。ただしパルプ試 料の場合は液底体律に上る影響を考慮して次式に上るも のとする。

$$
P^{\prime}=\frac{\sum_{m i} P_{i}}{\sum_{m_{i}}}
$$

このような重合度分布をるつたモデルがアルカリせル ロースになり老成反応により崩罜してゆくお㚈だが，こ

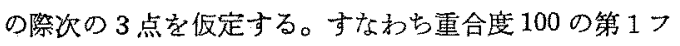
ラタションはアルカリ浸漬に私いて除去せられ老成に関 係せ妨こと。老成時に織維素の 1 部は炭酸ガスとなつて

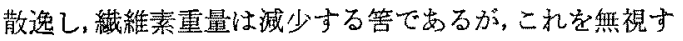

ること扰よび絏維素の棈造(たとえば結晶頒域量その他)

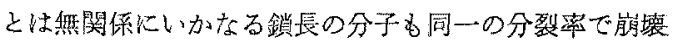
してゆくこと以上の 3 点である。第 1 の仮定は戦密には

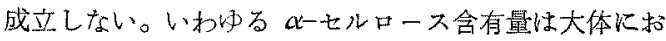
いてセルロースを最も膨潤させる 10\% 苛性ソーダ溶液 に上る溶解度に対応するものであって，実際のアルカリ

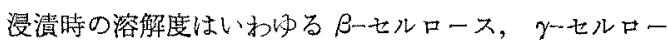
スの含量よりもはるか少い。しかし今娐定したもデル に関する限り重合度 100 のフラタションのアルカリセル 甘一ス中への残存移行の割合は, 以後の論識に大きな影

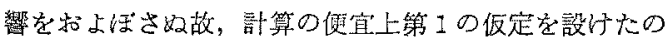
である。第 2 の仅定は炭酸ガスとなつて散逸する量が辰 野氏ら ${ }^{10)}$ に上机ば $20^{\circ} \mathrm{C}$ 老成の場合, 七ルロースに対し 1 \%前後であり微量であるから問題ない。第3の仮定はい ささか問題があると思われる。しかし Entwistle ら はアルカリセルローズの自動酸化の機權を合理的汇説明， し，普通用いられるアルカリ濃度に执いてはアルカリ七

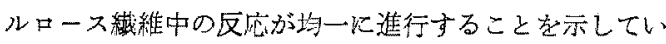
るし，また Samuelson ${ }^{12)}$ も老成アルカリ七ルロース， 精整リンター，重亚硫酸蒸解によるパルプ，次亜塩素酸 漂白パルプの重合度分有の比較からアルカリ老成が均一 反応でめつて，非晶領域中のみならず結晶領域中でも容 易に進行するとしている。したがつてこの仮定も成立す るすのと考克てよい。

さて各フラクションの崩燷は前述の桜田, 岡村式より 誘導された岡村氏 ${ }^{19}$ の式によつて計算した。岡村氏の式 は次の如く表現せられる。

$$
m P=1-\left\{1+\left(1-\frac{P v}{N}\right) \alpha . P u\right\} e-\alpha P v
$$

ここに $m P$ は分裂後に招いて試料の全量を1としたとき の重合度 $P v$ 以下のフラクションの量的割合を示すもの

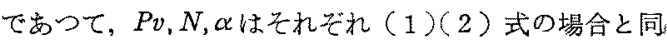
様の意味をるつ。（5）式により各重合度のフラクショ

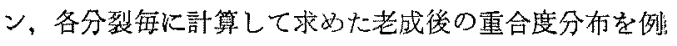
示すれば第 4 表の如くなる。

\begin{tabular}{|c|c|c|c|c|c|c|c|}
\hline \multirow{2}{*}{$\begin{array}{c}\text { 老成绻の重合度 } \\
(P)\end{array}$} & \multicolumn{7}{|c|}{ 初めのフラクションの重合度 $(N)$} \\
\hline & 3000 & 2000 & 1500 & 1000 & 800 & 500 & 300 \\
\hline 3000 & 0.0498 & & & & & & \\
\hline 2750 & 0.0665 & & & & & & \\
\hline 2250 & 0.1091 & & & & & & \\
\hline 2000 & - & 0.1353 & & & & & \\
\hline 1750 & 0.1650 & 0.1714 & & & & & \\
\hline 1500 & - & & 0.2231 & & & & \\
\hline 1250 & 0.1228 & 0.2451 & 0.2672 & & & & \\
\hline 1000 & - & & & 0.3679 & & & \\
\hline
\end{tabular}

第 4 表 分裂䖽 0.001 の各フラクシュンの重合度分布 


\begin{tabular}{|c|c|c|c|c|c|c|c|}
\hline 900 & 0.0999 & 0.1131 & 0.1267 & 0.1528 & & & \\
\hline 800 & - & & & & 0.4493 & & \\
\hline 700 & 0.0991 & 0.1143 & 0.1293 & 0.1600 & 0.1817 & & \\
\hline 550 & 0.0469 & 0.0547 & 0.0633 & 0.0774 & 0.0898 & & \\
\hline 500 & - & & & & & 0.6065 & \\
\hline 450 & 0.0436 & 0.0508 & 0.0572 & 0.0730 & 0.0835 & 0.1174 & \\
\hline 350 & 0.0381 & 0.0450 & 0.0517 & 0.0652 & 0.0754 & 0.1057 & \\
\hline 300 & - & & & & & & 0.7408 \\
\hline 250 & 0.0308 & 0.0363 & 0.0421 & 0.0533 & 0.0258 & 0.0873 & 0.1325 \\
\hline 150 & 0.0206 & 0.0247 & 0.0286 & 0.0366 & 0.0784 & 0.0602 & 0.0918 \\
\hline 50 & 0.0078 & 0.0093 & 0.0108 & 0.0138 & 0.0161 & 0.0229 & 0.0349 \\
\hline
\end{tabular}

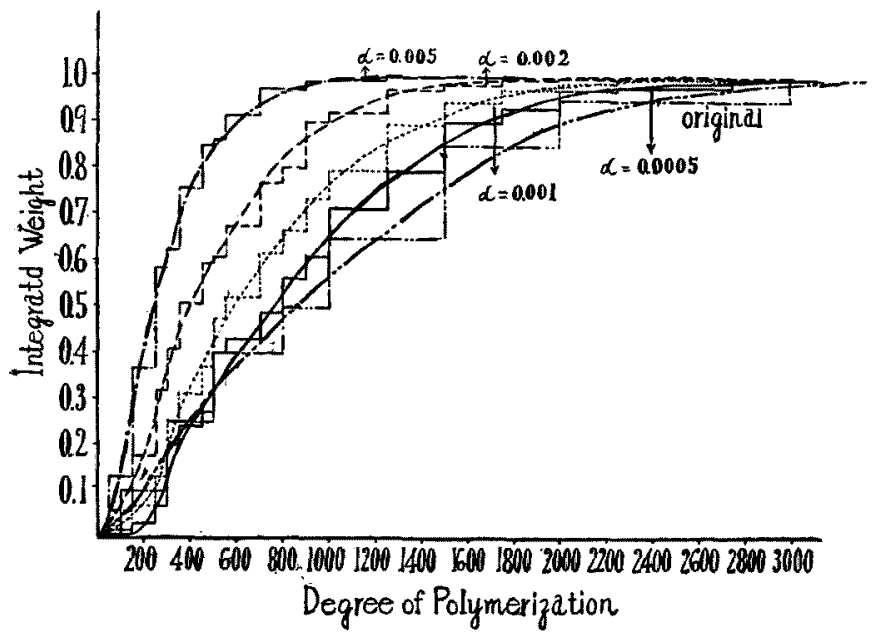

Fig. 1 Changes in chain length distributions of red pine pulp model during the alkali-aging.

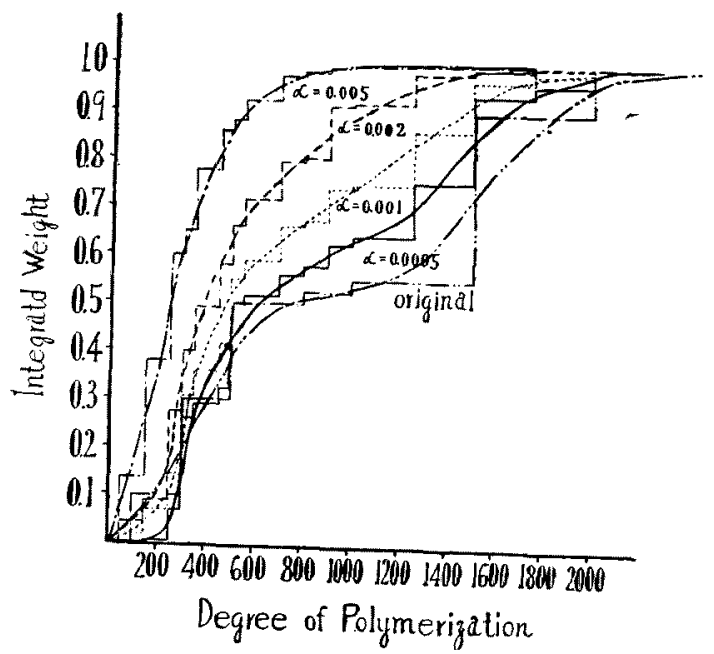

Fig. 2 Changes in chain length distributions of beech pulp model during the alkaliaging.
かくしてえた各フラクションの重合度分 布に原モデルに打ける各ィのフラクショ ンの重量比をかけて合成すると，それが 各分裂率に柾けるモデルの老成後の重合 度分有になる。その計算の一例を第 5 表 に示し計算結果を各モデル毎に第 1，2 図に揭げた。このよ5な計算による老成 時の重合度分布の変化は既往の重合度分 布実測結果 ${ }^{14) 15}$ と比較してみると，汃な りよく一致している。次にこの結果から (3) (4) 式に上り高銅法測定䛧江対広 する重合度分布全域にわたる重量平均重 合度 $P^{\prime}$ および低銅法測定值に対応する 重合度 2000 以上の部分をらくま双重量 平均重合度 $P$ を算出し，各々の分裂蜜を 求めてみると第 6 表の如くなる。

高銅法重合度

\section{低銅法重合度}

$$
\begin{aligned}
P & =(7902.5-1401.9) / 9.0011 \\
& =722
\end{aligned}
$$

第 6 蒜の結果に拈いても低銅法による ブナパルプモデルのアルカリ老成速度は 赤菘のそれより速い結果となるが，高銅 法の場合には活とんど差が点い。すな わち第 2 表と第 6 表とを比較して质ると ブナパルプより製造したアルカリセルロ ーズの老成速度が早くみえるのは，その 重合度分你の美之低銅高アンモニア組成 の銅安液による粘度測定結果のかたより によるものであることがかなり定量的に 説明せられると思われる。

\section{4. 総括および結論}


第 5 表 分裂宰 0.0005 の赤松アルカリセルロースの雷合度分布計算

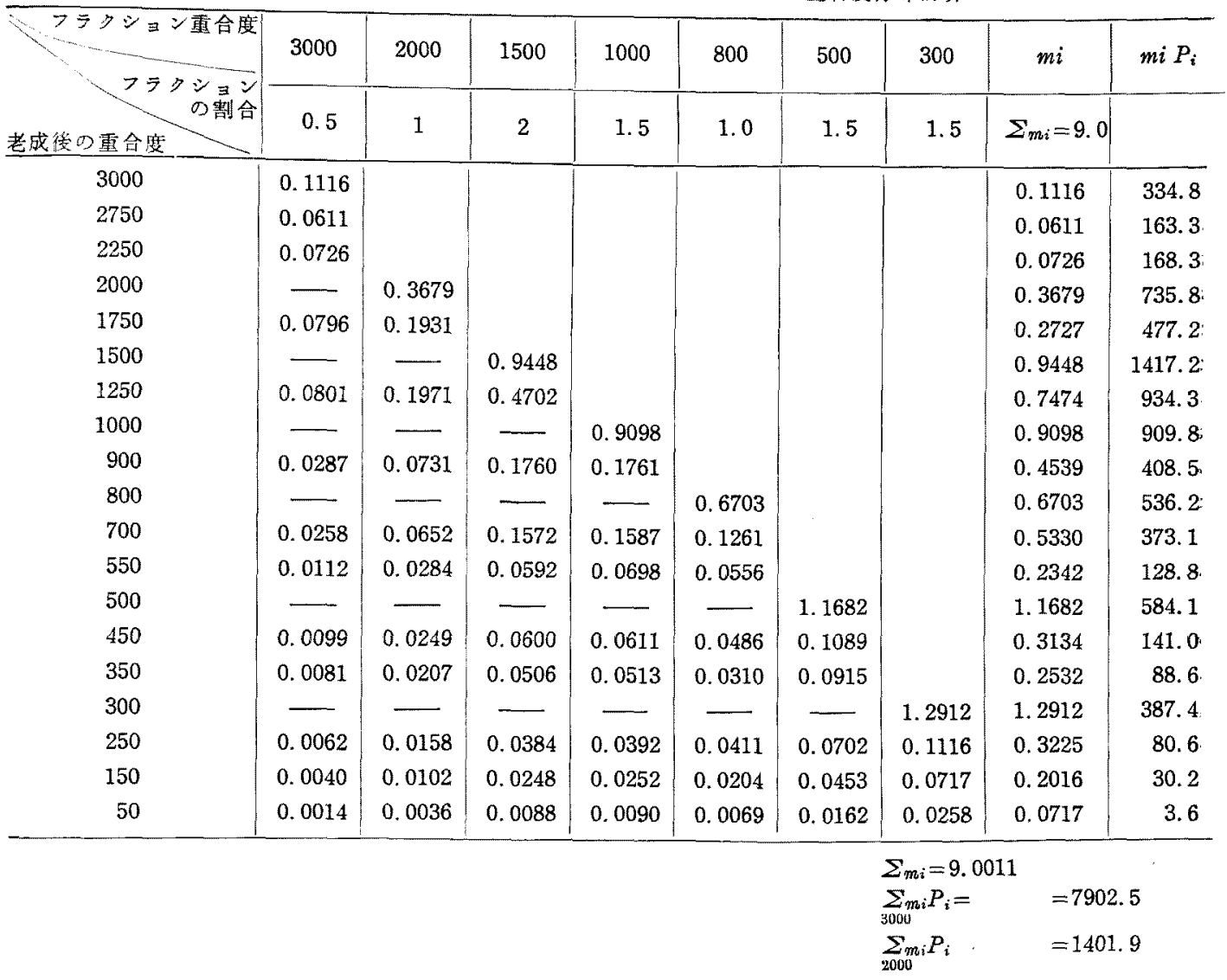

第 6 表 モデル老成に拈ける重合度と分裂茡

\begin{tabular}{|c|c|c|c|c|c|c|c|c|}
\hline \multirow{2}{*}{ 対応粘度测定法 } & \multicolumn{4}{|c|}{ 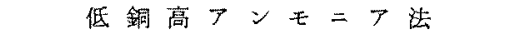 } & \multicolumn{4}{|c|}{ 高銅低 $フ ン モ=ア$ 法 } \\
\hline & \multicolumn{2}{|c|}{ 赤松パルプモデル } & \multicolumn{2}{|c|}{ ブナパルプモデル } & \multicolumn{2}{|c|}{ 赤松バルプモデル } & \multicolumn{2}{|c|}{ ブナパルブモデル } \\
\hline 各フラタションの分裂率 & D. $P$ & $\alpha \times 10^{4}$ & D. $P$ & $\alpha \times 10^{4}$ & D. P & $\alpha \times 10^{4}$ & D. $\mathrm{P}$ & $\alpha \times 10^{4}$ \\
\hline 0 & 765 & & 822 & & 1010 & & 940 & \\
\hline 0.0005 & 722 & 5.0 & 751 & 3.4 & 878 & 4.3 & 833 & 4.3 \\
\hline 0.0010 & 663 & 5.2 & 665 & 8.5 & 725 & 11.0 & 695 & 10.5 \\
\hline 0.0020 & 506 & 19.0 & 507 & 20.0 & 516 & 24.0 & 511 & 23.0 \\
\hline 0.0050 & 301 & 49.0 & 292 & 51.0 & 301 & 54.4 & 292 & 54.8 \\
\hline
\end{tabular}

1) プナパルプより製造したアルカリセルロースの老 成速度が赤松メ゚ルプのそれに比し速い上5に見充るの は，原パルブの重合度分布のらがいと一般に用いられ ている組成の銅液による粘度測定に蛒いて高重合度部分 が十分分散せず，粘度に関与しないことが組合わされて そのように観察されるのでむる。

2）これを定舅的に説明するため重合度分布のモデル
をつくり，このモデルについて岡村氏の式を使つて老成 後の状熊を推定して実测結果と比較しょい一致を見た。 本研究は祖父江教授の御指尊の下に行われたものでる る。銅安法重合度测定に協力せられた工藤耕一氏に感謝 する。また本研究の発表を許可せられた井戸川副社長, 援 助を賜わつた米谷工務部副部長に感謝する。なお本研究 梳瀻維学会昭和31年度春期研究発表会（昭和31年 6 月） 
に招いて㜔演した。

\section{文献}

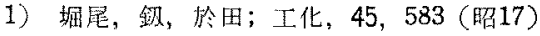

2) 辰野，越智; 㵶学蒜，6,316 (炤25); F. Bartell, H. Cowling ; Ind. Eng. Chem., 34, 607(1942)

3) F. Wnltsch ; Papierfabr., 10, 354 (1944)

4) 中井, 石田, 日高; 日化 73，19 (昭 27)

5) W.Bandel; Makromol. Chemie, 11, 87(1953)

6) 浅岡，鈴木，工藤；工化，59，161 (昭 31)

7) 㮃田, 抒村, 川绮：工化，45，1101（昭 17)

8) 小林, 丹沢；裁学誌，5，205(昭 24)
9)浅岡；本誌投稿中

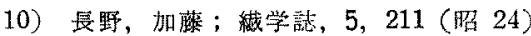

11) D. Entwistle, E. Coled, N. Wooding ; Text. Res. J., 19, 527 (1949)

12) O. Samuelson; Svensk Kem Tid., 59, 105 (1947)

13) 阔村；工化，45，1111 (昭 17)

14) 長野; 浅学誌, 5, 271 (昭 24)

15) H. Haas, E. Battenberg \& D. Teves; Tappi, $35,116(1952)$

32 年 9 月羊毛輸入国別表

（出所）大藏省税関部

\begin{tabular}{|c|c|c|c|c|c|c|c|c|c|c|c|}
\hline \multirow{2}{*}{ 国 } & \multirow{2}{*}{\multicolumn{3}{|c|}{ 名 }} & \multirow{2}{*}{$\frac{\text { 原 }}{\text { 千封度 }}$} & \multirow{2}{*}{$\frac{E}{f * 2}$} & \multirow{2}{*}{$\frac{\text { 洗 上 }}{\text { 千封倞 }}$} & \multirow{2}{*}{$\frac{\text { 羊 琶 }}{\text { †ドル }}$} & \multirow{2}{*}{ 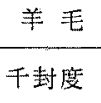 } & \multirow{2}{*}{ 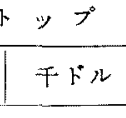 } & \multirow{2}{*}{$\frac{\text { 合 }}{\text { 偻 }}$} & \multirow{2}{*}{$\frac{\text { 部 }}{\text { 千ドル }}$} \\
\hline & & & & & & & & & & & \\
\hline 1 & $\xi$ & & $z$ & - & - & - & - & - & - & - & - \\
\hline 1 & ス & $x$ & r & - & - & - & - & - & - & - & - \\
\hline$v$ & ; & , & $y$ & 36 & 28 & - & - & - & - & 119 & 28 \\
\hline 英 & & & 国 & 10 & 11 & 9 & 12 & 64 & 80 & 455 & 104 \\
\hline$=$ & $\square \quad y$ & ビ & 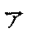 & - & - & - & - & - & - & - & - \\
\hline ヘ & $u$ & & - & 17 & 18 & - & - & - & - & 57 & 18 \\
\hline ブ & $\bar{F}$ & $\ddot{~}$ & r & 2 & 2 & - & - & - & - & 8 & 2 \\
\hline 수 & $\overline{7}$ & $T$ & イ & - & - & - & - & 29 & 48 & 169 & 48 \\
\hline$\dot{7}$ & ル & $\gamma$ & 1 & - & - & - & - & - & - & - & - \\
\hline 7 & ル ゼ & $y *$ & ン & 210 & 163 & - & - & - & - & 701 & 163 \\
\hline 南 & 阿 & 連 & 邦 & 466 & 441 & 3 & 3 & - & - & 1,573 & 444 \\
\hline オ & $-x+$ & $\bar{\nabla}$ & $\gamma$ & 15,039 & 14,882 & $\cdots$ & $\cdots$ & 137 & 205 & 50,936 & 15,088 \\
\hline$=1$ & $1-\ddot{E}$ & $\exists ン$ & $F^{*}$ & 286 & 253 & - & - & - & - & 954 & 253 \\
\hline$\approx$ & $n$ & $\neq$ & - & - & - & 22 & 23 & 65 & 114 & 500 & 137 \\
\hline r & 0 & & 他 & 36 & 33 & - & - & 30 & 65 & 294 & 97 \\
\hline 合 & & 計 & & 16,104 & 15,831 & 34 & 39 & 326 & 512 & 55,765 & 16,382 \\
\hline
\end{tabular}

（註）単位以下四陰五入，…印は単位未満又は不詳のすの，一印は雺を示す。 